\title{
CAROTENOID PIGMENTS IN THE OPTIC CUSHION OF MARTHASTERIAS GLACIALIS (L.)
}

\author{
By Norman Millott \\ Department of Zoology, University College of the West Indies, Jamaica, B.W.I.
}

\author{
and H. G. Vevers
}

The Plymouth Laboratory

(Text-figs. I-3)

Knowledge of the pigments of photosensitive structures in invertebrates is scanty; this is especially so in echinoderms. In other groups of animals and in plants, carotenoids have frequently been associated with light-sensitive processes (Wald, 1945), though their precise function is still uncertain.

Observations on the occurrence and distribution of carotenoids in various starfishes have been made by several authors whose work is reviewed by Fox (1953). Those in the integument of Asterias have recently been described by Vevers (1952), but, apart from the work of Lönnberg \& Hellström (I93I), and Lönnberg (1933), there have been no recent studies on the carotenoids of Marthasterias.

A study of the carotenoids in the light sensitive areas of echinoderms is therefore highly desirable, and the prominent and accessible 'eye spots' of $M$. glacialis (L.) form an obvious choice for such studies, although their functioning as photoreceptors has not yet been demonstrated experimentally in this species.

Several workers, especially Smith (1937), who reviewed the earlier work, have studied the structure of the 'eye spots' in this animal, but no special attention has been given to their pigments. In view of the possible importance of these pigments in visual physiology, it was decided to examine them in living material.

\section{Distribution of Pigment}

Individuals were obtained from trawl hauls taken in 20-30 fathoms off Plymouth and their optic cushions excised and examined under the microscope in sea water either directly, or in the form of frozen sections, in order to determine the distribution of pigment. It is essential to avoid the use of fixatives or processes causing shrinkage (as shown by Fox \& Millott, I954), or denaturation, and of solvents which leach out the pigment. Paraffin sections could not, therefore, be used.

The appearance of the excised optic cushion with its pigments is shown in Fig. I. The main anatomical and histological features of the organ (as they 
appear in fixed material), have already been described by Smith (1937) and will be mentioned here only in so far as they differ from previous accounts and are essential to understanding pigment distribution. In general form the optic cushion resembles a saddle astride the base of the azygos tentacle, measuring $1.5 \mathrm{~mm}$ in length in an average-sized specimen. It bears about 150 deeply pigmented cups (o.c.) disposed regularly in rows. Each cup is orientated with its long axis normal to the surface of the cushion, and most measured some I $50 \mu$ in length.

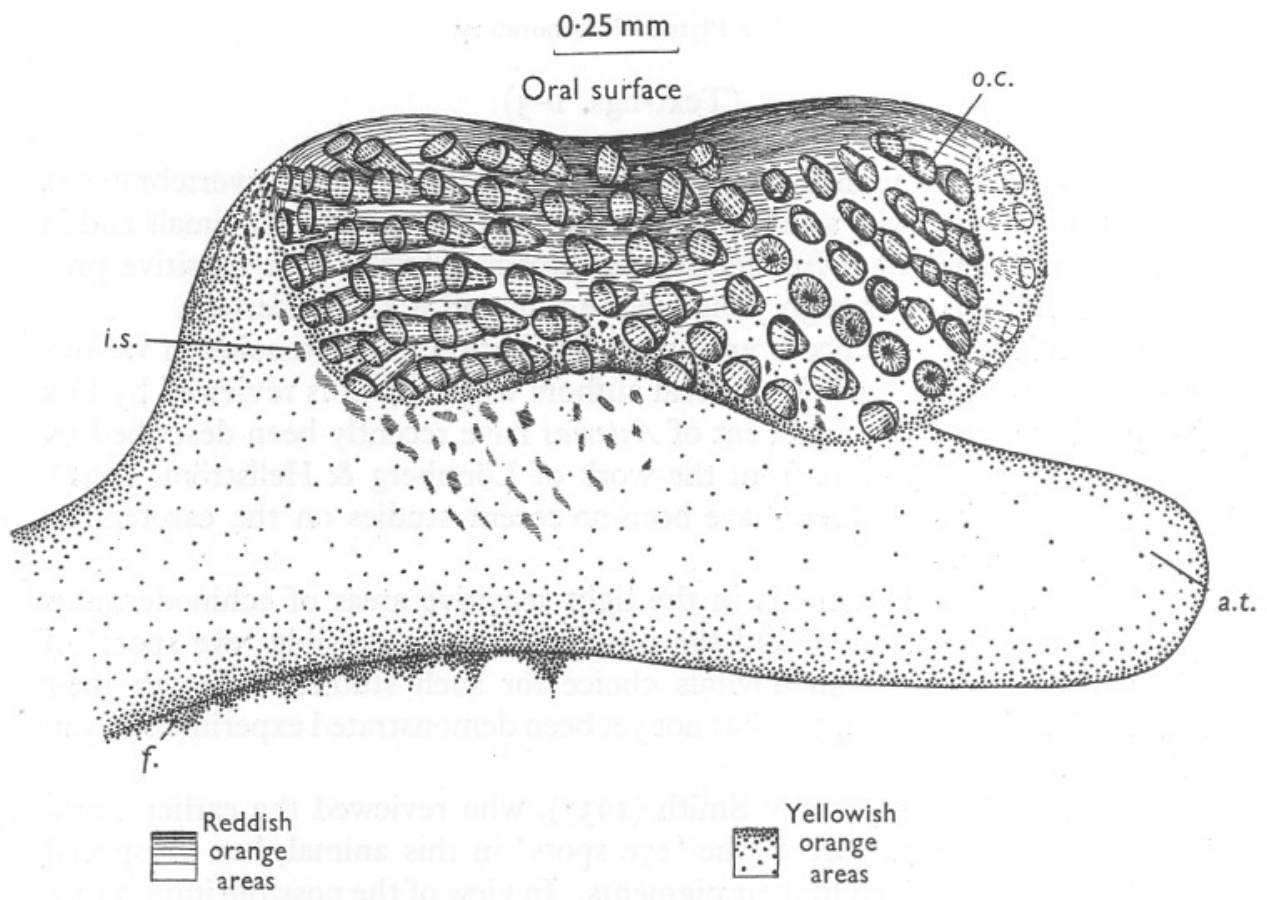

Fig. I. The optic cushion and azygos tentacle of Marthasterias glacialis as it appears when dissected from the arm tip. Semi-diagrammatic, side view, looking obliquely from the tip of the arm. a.t., azygos tentacle; $f$., fringe marking region where the cushion has been dissected away from the ambulacrum; i.s., one of the scattered, isolated spots of reddish orange pigment; o.c., optic cup.

The cups were called 'optic cups' by Smith, and though their functioning as photoreceptors has not been demonstrated directly, their structure and experimental evidence of the function of similar organs in other starfish justify at least tentative retention of the term.

The cushion and azygos tentacle is yellowish orange, whilst the cups are very conspicuous owing to their deep reddish orange colour. The latter pigment also occurs on the cushion in the form of irregular scattered spots (i.s.). 
In each cup, as shown in Fig. 2, the pigment is confined to certain cells (p.c.) in the wall, which as a result appears brilliant reddish orange in life; the cells at the bottom and around the rim of the cup appear to contain the most pigment. Between the reddish orange cells the wall of the cup appears pale yellow, and in these areas no cellular structure was discernible. It is essential to be cautious in interpreting this appearance, for it might be an artifact, the yellow areas being due to gaps between the deeply pigmented cells,

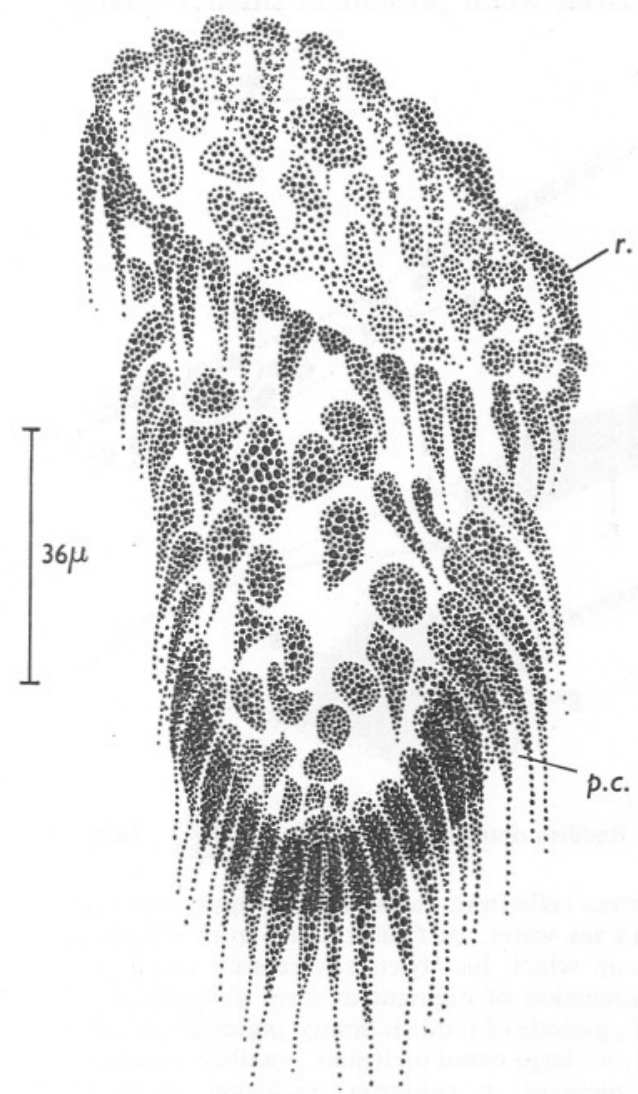

Fig. 2. The distribution of pigment cells in a single optic cup. Drawn from a fresh, unstained optic cushion mounted in sea water. No attempt has been made to show the precise character of cell contents. r., rim of cup; p.c., pigment cell.

caused by compression of the optic cup by the coverslip during examination. That this is not so is shown by the fact that such areas were observed in fresh cups examined by a water immersion objective and which were not, therefore, subjected to pressure.

Fig. 3 shows the form of the cells bearing the reddish orange pigment. Most are long and narrow with one end drawn out (Fig. 3A); some are irregular in 
form (Fig. 3 C, D) though still attenuated. Within the cell the precise disposition of pigment is difficult to determine. Undoubtedly some is carried in discrete red, or brownish, vacuoles or granules, measuring $0.5-2 \cdot 0 \mu(\mathrm{gv}$.$) , but$ more often the pigment is so dense as to prevent accurate observation. Though this can be made out in fresh material, it is more evident in cups which have been left beneath a coverslip for some hours, with the result that some of the pigment disappears (possibly due to oxidation, see p. 283), and observation becomes easier. Even when present in smaller quantity, however, we could

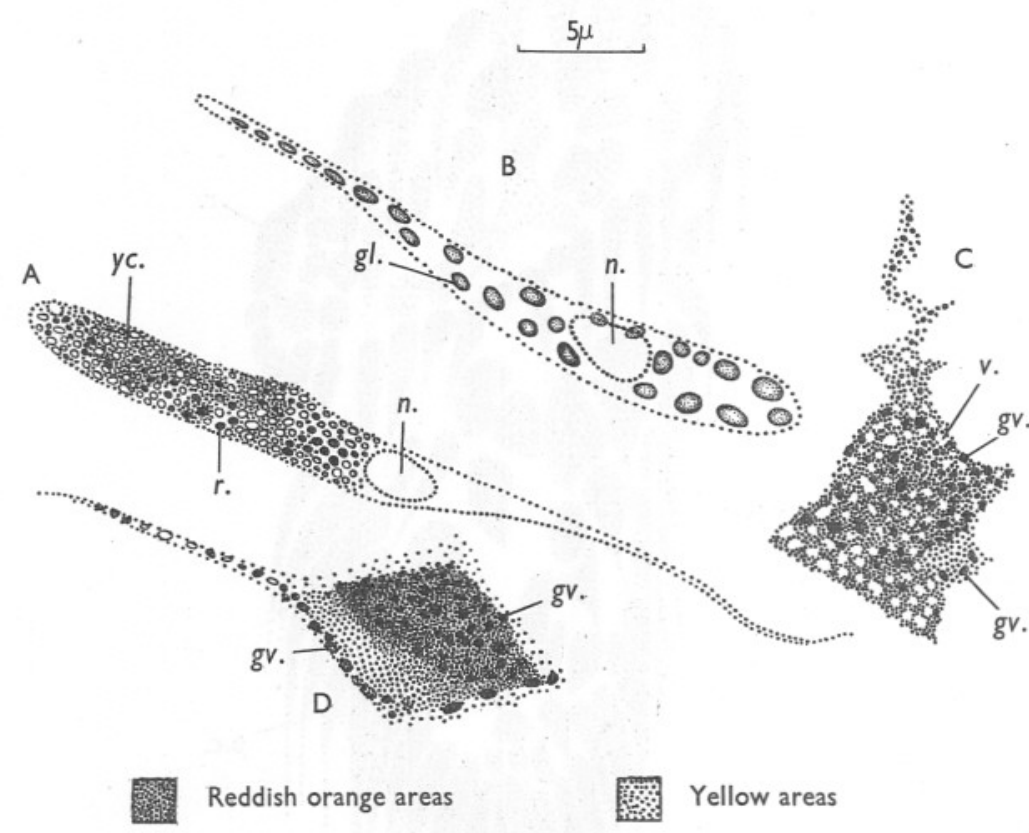

Fig. 3. Isolated pigment cells from the wall of the optic cup, drawn from unstained preparations mounted in sea water. A, fusiform cell from a fresh preparation; B, fusiform cell from an optic cup which had been compressed and left under a coverslip for $36 \mathrm{~h}$, showing the aggregation of pigment to form globules; C, D, irregular cells from fresh preparations. gl., globule of reddish orange pigment; gv., granule (or vacuole) of reddish orange pigment; $n$., large ovoid inclusion, possibly a nucleus; $r$., granule (or vacuole) of reddish orange pigment; $v$, colourless inclusion, or vacuole; $y c$., area of cytoplasm bearing yellowish pigment. The stipple key is applicable only to C and D.

not determine the precise way in which some pigment was carried, for it coloured the cytoplasm uniformly yellow or reddish orange, without any discernible association with discrete cellular inclusions (Fig. 3A, C and D).

A condition that may possibly be significant was observed in preparations which had been squashed or kept beneath a coverslip for $36 \mathrm{~h}$. In the resultant disorganization, the reddish orange pigment had aggregated into ovoid bodies (Fig. 3 B), suggesting that originally the pigment may have been disposed in the form of liquid, or semi-liquid, droplets. 


\section{Identification of the Pigments}

Previous investigations into the pigmentation of asteroids have shown the importance of carotenoids in the general body colour (e.g. Fox, 1953; Vevers, 1952). In $M$. glacialis previous work has suggested the presence of carotenes and xanthophylls (Lönnberg, I933; Lönnberg \& Hellstrom, I93I) and whole extracts of the integument have yielded no evidence of porphyrins, despite the occurrence of protoporphyrin in the integument of the related Asterias rubens (Kennedy \& Vevers, 1953).

Extracts of the optic cushions of Marthasterias were prepared as follows. The optic cushions and azygos tentacles of individuals from the hauls mentioned above were excised intact and freed from adhering integument. Some 200 of these were transferred to refined absolute methanol maintained in the dark in an atmosphere of nitrogen. Extraction was continued for about $\mathrm{I} 2 \mathrm{~h}$ to several days at room temperature, and produced an orange solution, leaving behind colourless tissue. It proved essential to conduct the extraction in nitrogen as the solution became colourless in a few hours if left in air.

The crude extract was examined in a Unicam S.P. 500 spectrophotometer for its absorption in the range $320-620 \mathrm{~m} \mu$. It showed a broad peak in the region of $472 \mathrm{~m} \mu$, suggesting that the colour is due to a mixture of carotenoids.

The pigments were further characterized by two methods.

\section{Method A}

Sufficient water was added to the extract to make a concentration of approximately $90 \%$ methanol and this was shaken with an equal volume of 'Analar' petroleum ether (B.P. $40-60^{\circ} \mathrm{C}$ ). Nearly all of the pigment passed into the petroleum ether epiphase, leaving only traces of yellow colour in the hypophase of which there was never sufficient for definite characterization. This pale yellow hypophase probably represented small amounts of xanthophylls. The epiphase was slowly evaporated to dryness on a warm bath, then dissolved in a small quantity of ethanol and saponified by warming the solution with $2 \frac{1}{2}$ times its volume of $\mathrm{KOH}$ (concentration of $\mathrm{I} 60 \mathrm{~g} \mathrm{KOH}$ in $106 \mathrm{ml}$ water). The resulting saponification mixture was cooled by adding distilled water and then extracted with di-ethyl ether. About two-thirds of the pigment passed immediately into the ether which was collected and evaporated to dryness. This formed fraction $a \mathrm{I}$.

The hypophase, which was in aqueous ethanolic $\mathrm{KOH}$, remained in the lower layer when shaken with more ether, and only passed into the epiphase on acidification with glacial acetic acid. This pigment was collected as fraction $a 2$.

The two fractions were examined spectrophotometrically and showed the absorption maxima (in $\mathrm{m} \mu$ ) given below:

$\begin{array}{ccc} & \begin{array}{c}\text { Carbon } \\ \text { disulphide }\end{array} & n \text {-hexane } \\ a_{1} & 484 & 450 \\ a_{2} & 499-500 & -\end{array}$




\section{Method B}

An extract similar to that used in method A was made and taken by dilution into 'Analar' petroleum ether. This was passed down a column of alumina (B.D.H. for chromatography) and elution was continued with petroleum ether. Two bands formed, one (the lower) being deep orange, the other (upper) pale orange. Development of the chromatogram was continued using $0.5 \%$ methanol in petroleum ether, until the two bands were well separated. They were then collected separately, the lower forming fraction $b \mathrm{I}$, the upper, fraction $b_{2}$. Both were taken into appropriate solvents for spectrophotometric determination of their absorption maxima which are reported (in $\mathrm{m} \mu$ ) below:

$\begin{array}{lcc} & \text { Carbon } & \\ & \text { disulphide } & n \text {-Hexane } \\ b_{1} & 485 & 449 \\ b_{2} & 503 & -\end{array}$

The phase partition behaviour of fraction $a \mathrm{I}$ and the behaviour on the chromatogram of fraction $b \mathrm{I}$, together with their absorption maxima, suggest that both are $\beta$-carotene.

The absorption maximum of fraction $b_{2}$ and its behaviour when chromatographed on alumina, suggest that it is esterified astaxanthin.

Fraction $a_{2}$ was epiphasic before saponification, but after this it became hypophasic and remained so when in alkaline solution. The absorption maximum of this portion after saponification suggested astacene, and this, together with the original phase partition behaviour, indicates derivation from esterified astaxanthin.

\section{The EfFect of Exposure to Light}

A methanol extract of optic cushions in an atmosphere of nitrogen, contained in a tube of ordinary glass, was irradiated by a 'Hanovia' ultra-violet lamp. Care was taken to place the solution far enough from the lamp to avoid any significant rise in temperature. The optical density of the extract was determined in the region of its maximum absorption in the visible range. Before irradiation $\log E$ was found to be $4 \mathrm{I} 3$ at $476 \mathrm{~m} \mu$. After I h irradiation, it had fallen to 404 at $476 \mathrm{~m} \mu$ and after a further $2 \mathrm{~h}$, to 276 at the same wavelength. At least one of the pigments is therefore unstable in light.

\section{Discussion}

The discovery of $\beta$-carotene and astaxanthin in the optic cushions of Marthasterias is not surprising in view of their occurrence in the integument of Asterias (Vevers, 1952), and since $\beta$-carotene has been reported as the predominant carotene in asteroids (Fox, I953).

It would appear from considerations of molecular size, that the yellowish orange colour is due to $\beta$-carotene, while the darker reddish orange is due to 
esters of astaxanthin. If this is so, from appearances under the microscope, $\beta$-carotene is widely distributed in the cushion while astaxanthin appears confined to the optic cup and pigment cells scattered irregularly over the surface of the cushion. Both pigments appear to exist in some of the pigmented cells of the optic cups, although it is not yet clear whether they occur free, or combined, for example, with protein. As regards astaxanthin, combination with protein appears unlikely, since the pigment does not appear in the living optic cushion with the dark hues commonly associated with such a combination, and correlated with this is the fact that the colour of the optic cushion is not markedly changed by a denaturant such as methanol. Some of the reddish orange colour could, however, be due to molecular associations involving $\beta$-carotene.

Our findings concerning the appearance of the pigment-bearing cells of the optic cup differ somewhat from those of Smith (I937), who described them as prolonged into tails which are bent so as to lie parallel to the long axis of the optic cup, with their pigment in granular form, confined to the outer third of the cell.

As will be evident from Fig. 2, the form and disposition of the pigment cells leaves no doubt that they correspond to the cells similarly distinguished by Smith, but we find that their abundant pigment is present throughout the cytoplasm. It is also noteworthy that they are about twice the size of those figured by Smith. As previously noted, some of the cells are irregular, though still attenuated.

In general, these differences can be reconciled with the different methods used, for the preparation of paraffin sections by Smith's methods would not only leach out and destroy the carotenoid pigments, but would also cause shrinkage. What the granular pigment mentioned by Smith may be, we cannot suggest, for we saw nothing in the living optic cups that might correspond with it.

As noted by Smith, who reviewed the earlier work, the histology of the optic cup is difficult, but he concluded that it is lined by cells that bear pigment and those that are sensory. A study of the histology of the cup is beyond the scope and methods of this investigation, but we feel it necessary to urge caution in discriminating between sensory and pigmented cells on histological grounds alone. For if the lining of the optic cups is truly photosensory (see below), then since the very nature of the photoreceptive process renders a light absorber necessary, the possession of an orange or yellow pigment absorbing at the high-energy end of the spectrum would seem to constitute an admirable adaptation for this. It is thus possible that the pigment cells are also sensory.

There is general agreement that asteroids are light sensitive, but since the function of the optic cushions in Marthasterias has not yet been demonstrated, the role of the carotenoid pigments must remain uncertain. Nevertheless, it must be admitted that in so far as their structure is concerned (see Smith, 
I937), the optic cups present evidence of participation in some form of light perception, though due caution must be exercised in using such evidence alone. Furthermore, in the related Asterias, the 'eye spot' has been shown unquestionably to be photosensitive by Hartline, Wagner \& MacNichol (1952), who recorded its action potential in response to stimulation by. light. In addition, however, evidence has accumulated showing that photosensitivity in starfish is not confined to the eye spot and may extend to the tube feet, and, as in other echinoderms, to the general body surface (Cowles, I9IO, I9II; v. Frisch, I909; McCurdy, I9I2; Mangold, I909; Millott, I955; van Weel, I935).

The discovery of the same carotenoids in the optic cushion of Marthasterias as have been found in the skin of other asteroids, may be significant in possibly providing a clue to the common basis of photosensitivity in these areas, especially since carotenoids have been found in a wide variety of photosensitive structures (Wald, I945).

If such an indication proves to be well founded, then the optic cushion might well represent a localized concentration of such skin pigments and constitute a stage in the evolution of the condition where photosensitivity is largely confined to highly specialized eyes.

It must be borne in mind, however, that these pigments may not be the only ones occurring in the optic cushion, for the methods of observation and extraction used here would not reveal any fugitive photosensitive pigments of the rhodopsin type, and neither time nor the amount of material available permitted us to determine whether there were other indications of such pigments in the form of vitamin A. There is also the possibility that the pigments may play only a secondary part in light perception by acting as filters, etc. Astaxanthin appears to play such a role in some specialized eyes (Wald, I945).

Regrettably the experiments made to determine whether the pigments were stable in light could not be completed. Though decomposition occurred, it appears too slow to be significant in vision, but as the pigments were dissolved in methanol they were far removed from their normal chemical environment. Such stability, however, would not in itself prevent the pigments from functioning in photoreception, since their primary function of absorbing light energy would be discharged, whether they remained intact, or were decomposed and reformed.

We wish to thank Dr G. A. Steven and the crews of the Plymouth research vessels for their efforts in obtaining material for us during inclement weather. Our thanks are also due to $\mathrm{Mr} \mathrm{F}$. A. J. Armstrong for help and suggestions, and to Prof. J. E. Smith who has kindly read the manuscript. One of us (N.M.) wishes to acknowledge the generosity of the Director and Staff of the Plymouth Laboratory in providing facilities for research. 


\section{SUMMARY}

The optic cushion of Marthasterias glacialis is seen to contain yellowish orange and reddish orange pigments. The former occurs throughout the cushion, the latter is confined to the wall of the optic cups and a few scattered, irregular patches. Both pigments occur in the cytoplasm of long and narrow or irregular cells, some in the form of granules or vacuoles.

Optic cushions yield an orange extract in methanol which decomposes in light.

The behaviour of methanolic extracts after partitioning, saponification, chromatographic separation and spectrophotometric examination indicates the presence of $\beta$-carotene and esterified astaxanthin.

The significance of the results in relation to previous findings and their possible bearing on photoreception is discussed.

\section{REFERENCES}

Cowles, R. P., I9I0. Preliminary report on the behavior of echinoderms. Yearb. Carneg. Instn, no. 8, pp. I28-9.

- I9II. Reaction to light and other points in the behavior of the starfish. Pap. Tortugas Lab., Vol. III, pp. 97-I Io.

Fox, D. L. 1953. Animal Biochromes and Structural Colours. Cambridge University Press.

Fox, D. L. \& Millott, N., I954. The pigmentation of the jellyfish Pelagia noctiluca (Forskål) var. panopyra Péron and Lesueur. Proc. roy. Soc. B, Vol. I42, pp. $392-408$.

FrISCH, K. vON., I909. Biologie des Seesterns Asterias forreri. Naturw. Wschr., N.F., Bd. 8, pp. 488-9I.

Hartine, H. K., WAgner, H. G. \& MacNichol, E. F. Jnr., I952. The peripheral origin of nervous activity in the visual system. Cold Spr. Harb. Symp. quant. Biol., Vol. 17, pp. I25-4I.

KenNedy, G. Y. \& VeVers, H. G., 1953. The biology of Asterias rubens. L. V. A porphyrin pigment in the integument. F. Mar. biol. Ass. U.K., Vol. 32, pp. 235-47.

LöNNBERG, E. I933. Zur Kenntnis der Carotinoide bei marinen Evertebraten. Ark. Zool., Bd. 25A, Nr. I., I7pp.

LönNBerg, E. \& HellströM, H., I93I. Zur Kenntnis der Carotinoide bei marinen Evertebraten. Ark. Zool., Bd. 23A, Nr. 15, 74pp.

MacCurdy, H. M., I9I2. Observations on the reactions of Asterias forbesii to light. Science, N.S., Vol. 35, p. 192.

MANGOLD, E., I909. Sinnesphysiologische Untersuchungen an Echinodermen. Ihre Reaktionen auf Licht und Schatten und die negative Geotaxis bei Asterina. Z.allg. Physiol., Bd. 9, pp. I12-46.

Millot, N., I954. Sensitivity to light and the reactions to changes in light intensity of the echinoid Diadema antillarum Philippi. Phil. Trans. B, Vol. 238, pp. 187-220.

SмIтн, J. E., I937. On the nervous system of the starfish Marthasterias glacialis (L). Phil. Trans. B, Vol. 227, pp. II I-73.

Vevers, H. G., I952. The biology of Asterias rubens L. III. Carotenoid pigments in the integument. F. Mar. biol. Ass. U.K., Vol. 30, 569-74.

WaLD, G., I945. The chemical evolution of vision. Harvey Lect., Ser. 4I, pp. I I7-60. WEEL, P. B. VAN, 1935. Úber die Lichtempfindlichkeit der Ambulakralfüsschen des Seesterns (Asterias rubens). Arch. neerl. Zool. T. I, pp. 347-53. 